Journal of Southeast Asian

\title{
Selected Poems: Write More, Create More, Say More; Koun Khmer, Neariy Khmer
}

Phira Azalli-Chriissnia Rehm

rehmdesigningteam@gmail.com

Follow this and additional works at: https://docs.lib.purdue.edu/jsaaea

\section{Recommended Citation}

Rehm, Phira Azalli-Chriissnia (2013) "Selected Poems: Write More, Create More, Say More; Koun Khmer, Neariy Khmer," Journal of Southeast Asian American Education and Advancement: Vol. 8 : Iss. 1, Article 18.

DOI: $10.7771 / 2153-8999.1073$

Available at: https://docs.lib.purdue.edu/jsaaea/vol8/iss1/18

This document has been made available through Purdue e-Pubs, a service of the Purdue University Libraries. Please contact epubs@purdue.edu for additional information.

This is an Open Access journal. This means that it uses a funding model that does not charge readers or their institutions for access. Readers may freely read, download, copy, distribute, print, search, or link to the full texts of articles. This journal is covered under the CC BY-NC-ND license. 


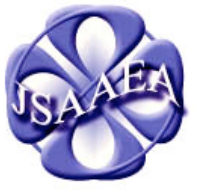

Volume 8 (2013)

\section{Journal of Southeast Asian American Education \& Advancement}

WWw.JSAAEA.org
A peer-reviewed scholarly journal published by the National Association for the Education \& Advancement of Cambodian, Laotian, and Vietnamese Americans (NAFEA)

\section{Selected Poems}

\section{by \\ Phira Rehm}

\section{Write More, Create More, Say More}

Saasay chroeun, Bangkaoet ... bandoh aoy chroeun, Niyeay chroeun ... prap aoy doeung ... kom bambat chaol

(Write more, Create ... cultivate more, Say more ... tell so people know ... do not forget it)

Write more, Create more, Say more

Ma thaa, prueh neang khnyom trov kaa doeung

She says, for I need to know,

Neang khnyom trov kaa banghanh plov dal kone chao

I need to show my children the way

It is always this way, no matter which day

Her ears are intent, she continues the wait

Each word is precious, each memory treasured

Each breath she takes

Saasay chroeun, Bangkaoet ... bandoh aoy chroeun, Niyeay chroeun ... prap aoy doeung ... kom bambat chaol

(Write more, Create ... cultivate more, Say more ... tell so people know ... do not forget it)

Write more, Create more, Say more

Ma thaa, prueh neang khnyom trov kaa doeung

She says, for I need to know,

Thngay muey neang khnyom noeng banghanh plov dal kone chao

One day I'll show my children the way

As the years wither away

Each word, each memory becomes faint

Remembering is pain, not knowing is sure death

Won't you tell me before your last breath?

\section{(C)}

SOMERIGHISRESERED Readers are free to copy, display, and distribute this article, as long as the work is attributed to the author(s) and the Journal of Southeast Asian American Education \& Advancement, it is distributed for noncommercial purposes only, and no alteration or transformation is made in the work. More details of this Creative Commons license are available at http://creativecommons.org/licenses/by-nc-nd/3.0/. All other uses must be approved by the author(s) or JSAAEA. 
Saasay chroeun, Bangkaoet ... bandoh aoy chroeun, Niyeay chroeun ... prap aoy doeung ... kom bambat chaol

(Write more, Create ... cultivate more, Say more ... tell so people know ... do not forget it)

Write more, Create more, Say more

Ma thaa, prueh neang khnyom trov kaa doeung

She says, for I need to know

Neang khnyom trov kaa banghanh plov dal juun jeat yueng

I need to show our people the way

Your pain, your suffering is not in vain

Release them to me, don't pocket your fears

There is fierceness in me, I'll stand for truth

Don't end it with the cycle of psychological abuse

Saasay chroeun, Bangkaoet ... bandoh aoy chroeun, Niyeay chroeun ... prap aoy doeung ... kom bambat chaol

(Write more, Create ... cultivate more, Say more ... tell so people know ... do not forget it)

Write more. Create more. Say more.

Ma thaa, prueh neang khnyom trov kaa doeung

She says, for I need to know

Thngay muey neang khnyom noeng banghanh plov dal juun jeat yueng

One day I'll show our people the way

Ma speaks,

My child, I fought far too long

My time is up, My life is gone

You are My strength, you are My legacy

I trust in you to carry Me, in truth, in honesty

My silence is not fear, it's instilled in Me

My pain is My own, my suffering is karma, you see?

I will not pass down to you what was passed down to Me

I will not instill in you, what was instilled in me

I was taught to be silent, I was taught to please

Jiivit Ma min maen robah Ma te, Jiivit Ma daoembey prae doch maassine, doch obpakaa

(My Life is not mine, My life is for use like a machine, like an instrument)

A life, not my own, but a machinery

Saasay chroeun, Bangkaoet ... bandoh aoy chroeun, Niyeay chroeun ... prap aoy doeung ... kom bambat chaol

(Write more, Create ... cultivate more, Say more ... tell so people know ... do not forget it)

Write more. Create more. Say more.

Ma thaa, prueh neang khnyom doeung

She says, for I know

Jiivit khnyom noeng min maen doch Ma te

My life WILL NOT be the same as yours 
Koun Khmer, Neariy Khmer

(Child of Khmer, Lady of Khmer)

"Khmer child, Khmer woman"

Koun Khmer, Neariy Khmer

(Child of Khmer, Lady of Khmer)

"Khmer child, Khmer woman"

Her eyes will always see past her disappointments

the unspoken words buried deep within her being

her dreams of her eldest as the seam that binds culture and tradition

Unraveling

Koun Khmer, Neariy Khmer

(Child of Khmer, Lady of Khmer)

"Khmer child, Khmer woman"

Weak! I don't want your cries!

Be strong! Silence is strength

Keep it inside! Don't show your heart

Don't allow for others to see into your soul

Whore!

Koun Khmer, Neariy Khmer

(Child of Khmer, Lady of Khmer)

"Khmer child, Khmer woman"

Walk softly, speak softly, sit with respect

No ambitions, no talents, you will be bred

to be the best cook, mother, wife, and daughter

Your life is mine and for no other

Stupid!

My LIFE, My BEAUTY

Dear mother, I tried my best

To do everything you've taught me

To never forget

But my beauty will not allow for deterioration

My life will not allow for no other master

My LIFE

I cry with heart and feeling

I cry for you; for healing

My heart is full; my will is my strength

I will not keep it inside; I will not forget 
My soul is beautiful how could it hide?

My being is soulful; it is full of pride

I speak, walk, and sit with respect

But not as softly as you would expect

My ambitions and talents are bountiful

I am a great cook, mother, daughter, wife, artist, woman, human

My LIFE is my own, just how it should have been for you

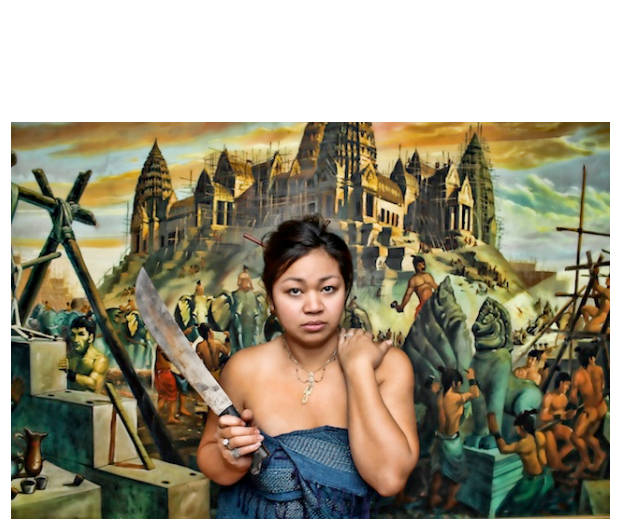

\section{About the Author}

Phira Rehm is a first generation Khmer Minnesotan artist born in a refugee camp, Khao I Dang/Site II in Mairut, Thailand and raised in Minnesota. In 1999, Phira founded Khmer's Next Generation. The organization focuses on utilizing Arts and Crafts to bridge the gap in communication, culture, and traditions between elders and youths in the Southeast Asian Communities. For Phira, art IS a tool for expression and a process through which she can achieve freedom and recognition of self from oppression and without censorship. Phira uses her art to create a dialog about the issues in society that people tend to sweep under the rug or hide behind masks in hopes of initiating change and inspiration for her and others. Her current artistic vision is to stop the silent sufferings of women and children within the Southeast Asian community, who have experienced sexual abuse, molestation, and rape, by utilizing art as a way to help find their voices to tell their stories and begin the process of healing and self-love.To learn more about Phira Rehm please visit: www.mnartists.org/Phira_Rehm or http://khmersnextgeneration.wordpress.com/ 


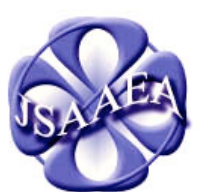

Volume 8 (2013)

\section{Journal of Southeast Asian American Education \& Advancement}

\author{
WwW.JSAAEA.org
}

\section{Editor}

Dr. Wayne E. Wright

University of Texas, San Antonio

\author{
Associate Editors \\ Dr. Chhany Sak-Humphry \\ University of Hawaii at Manoa
}

Dr. Phitsamay Sychitkokhong Uy

University of Massachusetts, Lowell

\section{Book Review Editor}

Dr. Vichet Chhuon

University of Minnesota

\section{Creative Works Editor \\ Bryan Thao Worra \\ Lao Assistance Center}

Special Advisor

Gregory Green

Curator, Echols Collection on Southeast Asia, Cornell University Library

\author{
Journal Manager \\ Sovicheth Boun \\ University of Texas, San Antonio
}

A peer-reviewed scholarly journal published by the

National Association for the Education \& Advancement of Cambodian, Laotian, and Vietnamese Americans (NAFEA)

Comments and questions for the editorial staff may be directed to jsaaea@lists.sis.utsa.edu

\section{Editorial Review Board}

\author{
Dr. Steve Arounsack \\ California State University, Stanislaus \\ Dr. Phala Chea \\ Lowell Public Schools \\ Dr. Loan Dao \\ University of Massachusetts, Boston \\ Dr. Changming Duan \\ University of Missouri, Kansas City \\ Dr. Jeremy Hein \\ University of Wisconsin - Eau Claire \\ Dr. Samlong Inthaly \\ Minneapolis Public Schools \\ Dr. Kevin K. Kumashiro \\ University of Illinois, Chicago
}

\author{
Dr. Carl L. Bankston III \\ Tulane University \\ Dr. George Chigas \\ University of Massachusetts, Lowell \\ Dr. Hien Duc Do \\ San Jose State University \\ Dr. Sophal Ear \\ U.S. Naval Postgraduate School \\ Dr. Nancy H. Hornberger \\ University of Pennsylvania \\ Dr. Peter Nien-Chu Kiang \\ University of Massachusetts, Boston \\ Dr. Ha Lam \\ Arizona State University
}




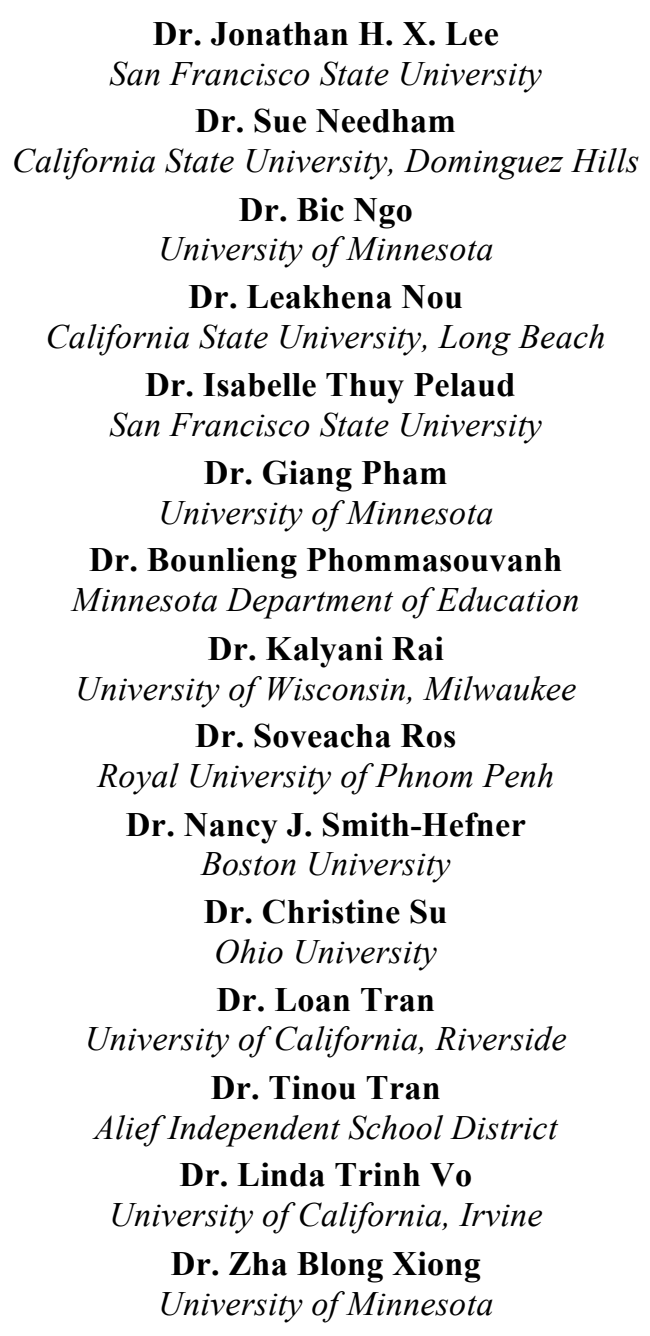

Dr. Jonathan H. X. Lee

Dr. Sue Needham

Dr. Bic Ngo

Unersity of Minnesota

ia State University, Long Beach

Dr. Isabelle Thuy Pelaud

Dr. Giang Pham

University of Minnesota

Dr. Bounlieng Phommasouvanh

Dr. Kalyani Rai

Dr. Soveacha Ros

oyal University of Phnom Penh

Boston University

Dr. Christine Su

Ohio University

Dr. Tinou Tran

Dr. Linda Trinh Vo

University of Minnesota

Dr. Stacey Lee

University of Wisconsin, Madison

KimOanh Nguyen-Lam

U.S. Department of Education

Dr. Max Niedzwiecki

Daylight Consulting Group

Dr. Clara Park

California State University, Northridge

Dr. Mark Pfeifer

SUNY Institute of Technology

Dr. Loan T. Phan

University of New Hampshire

Dr. Karen Quintiliani

California State University, Long Beach

Dr. Angela Reyes

Hunter College, The City University of New York

Dr. Fay Shin

California State University, Long Beach

Dr. Cathy J. Schlund-Vials

University of Connecticut, Storrs

Dr. Yer J. Thao

Portland State University

Dr. Myluong Tran

San Diego State University

Dr. Khatharya Um

University of California, Berkeley

Dr. Terrence G. Wiley

Center for Applied Linguistics

Dr. Kou Yang

California State University, Stanislaus

\section{Doctoral Student Editorial Review Board}

Virak Chan

University of Texas, San Antonio

Annie BichLoan Duong

San Joaquin County Office of Education

Peter Tan Keo

Columbia University

Monirith Ly

Texas State University-San Marcos

Hoa Nha Nguyen

University of Minnesota

Vanna Som

Harvard University

Krissyvan Truong

Claremount Graduate University

Yang Sao Xiong

University of California, Los Angeles
Keo Chea-Young

University of Pennsylvania

Ketmani Kouanchao

California State University, Fullerton

Ravy Lao

University of California, Santa Barbara

Thien-Huong Ninh

University of Southern California

Malaphone Phommasa

University of California, Santa Barbara

Alisia Tran

University of Minnesota

Silvy Un

University of Minnesota

Yeng Yang

University of Texas, San Antonio 